\title{
Flerumettede fettsyrer og epilepsi
}

\begin{abstract}
Sammendrag
Bakgrunn. Vel $30 \%$ av dem som lider av epilepsi, har farmakoresistente anfall. Av den grunn pågår det en intens jakt på alternative behandlingsmetoder. Barn med alvorlig epilepsi er blitt behandlet med ketogen diett, med gode resultater. Flerumettede fettsyrer bidrar i hvert fall delvis til denne anfallsreduserende effekten. Kanskje kan disse fettsyrenes antiepileptiske egenskaper utnyttes terapeutisk?
\end{abstract}

Materiale og metode. Etter ikke-systematiske søk i Cochrane-databasen og PubMed til og med mai 2008 ble artikler selektert etter gjennomlesing av sammendraget ut fra relevans til temaet. Spesielt la vi vekt på kliniske aspekter. Søkeordene var «epilepsy», «polyunsaturated fatty acids», «clinical trials», «ketogen diet» og «treatment».

Resultater og fortolkning. Artikler om kliniske fors $\varnothing$ og laboratoriefors $\varnothing k$ ble funnet på PubMed, studier vedrørende ketogen diett er hentet fra Cochranedatabasen. Flere dyrefors $ø$ k og en klinisk studie har vist at økt inntak av flerumettede fettsyrer gjennom ulike biokjemiske mekanismer kan motvirke tendensen til epileptiske anfall. Men så langt er det ikke sikkert påvist at flerumettede fettsyrer har anfallsreduserende effekt hos mennesker med epilepsi. Om de vil kunne bli et fremtidig behandlingsalternativ, er det for tidlig å si. Mer forskning er nødvendig.

\author{
Anette Huuse Farmen \\ anette.huuse.farmen@sykehuset-innlandet.no \\ Nevrologisk avdeling \\ Sykehuset Innlandet Lillehammer \\ Anders Sandviks gate 17 \\ 2609 Lillehammer \\ Morten I. Lossius \\ Barne- og ungdomsavdelingen \\ Epilepsisenteret-SSE \\ Nevroklinikken \\ Rikshospitalet \\ og \\ HØKH Forskningssenteret \\ Akershus universitetssykehus

\section{Karl 0. Nakken} \\ Epilepsisenteret-SSE \\ Nevroklinikken \\ Rikshospitalet
}

Epilepsi rammer i underkant av $1 \%$ av befolkningen. Hos rundt $70 \%$ av disse kan anfallene bringes under kontroll med medikamenter (1). I den senere tid er det kommet data som indikerer at tilskudd av omega-3fettsyrer kan ha positive effekter på sykdommer i nervesystemet, som for eksempel Alzheimers sykdom og multippel sklerose $(2,3)$. Noen dyrestudier $(4,5)$ og enkelte kliniske observasjoner $(4,6,7)$ tyder på at flerumettede fettsyrer også kan ha antiepileptiske egenskaper. Ketogen diett er allerede i bruk i epilepsibehandlingen, særlig hos barn med alvorlige epileptiske encefalopatier $(8,9)$. Selv om mekanismene bak den anfallsreduserende effekten av dietten er uklar, spiller trolig den diettinduserte økningen av flerumettede fettsyrer i hjernen en viktig rolle.

Hensikten med denne artikkelen er å gi en kort oversikt over hva man i dag vet om hvorledes flerumettede fettsyrer kan påvirke sykdommen, og drøfte hvorvidt de kan ha en fremtidig plass i epilepsibehandlingen.

\section{Materiale og metode}

Vi har gått ut fra et utvalg av artikler funnet etter et ikke-systematisk litteratursøk i Cochrane-databasen og PubMed til og med mai 2008 med søkeordene «epilepsy», «polyunsaturated fatty acids», «clinical trials», «ketogen diet» og «treatment».

\section{Resultater}

Artikler vedrørende kliniske forsøk og laboratorieforsøk ble funnet på PubMed, mens materiale vedrørende ketogen diett er hentet også fra Cochrane-databasen. I følgende avsnitt presenteres og diskuteres de aktuelle funnene.

\section{Kort om fettsyrer}

Fettsyrer kan deles inn i mettede og en- eller flerumettede, avhengig av antall doble kjeder i molekylet. Essensielle fettsyrer er fettsyrer som kroppen ikke kan lage selv. I kosten finnes fettsyrene $\mathrm{i}$ forskjellige matsorter (tab 1).

Fettsyrene er nødvendige for menneskets normale utvikling og fungering. Blant annet er de viktige for oppbygging og funksjon av cellemembranene og deres stabilitet, permeabilitet, eksitabilitet og reseptorfunksjoner. En norsk studie viste at syntese av omega-3-fettsyren dokosaheksaensyre prioriteres i hjernen. Selv om denne fettsyren representerer bare $0,25 \%$ av energien i kostholdet, utgjør den omkring $10 \%$ av fettsyrene i hjernen og halvparten av fettsyrene i synscellene (10). Dokosaheksaensyre er også funnet i store konsentrasjoner i nevronale synapser (2). Eikosapentaensyrekonsentrasjonen i hjernen er lav og utgjør der under $1 \%$ av fettsyrene.

\section{Ketogen diett}

Denne dietten ble introdusert i epilepsibehandlingen på begynnelsen av 1900-tallet som en følge av erfaringen at langvarig faste, med ledsagende ketose, ga færre anfall hos epilepsipasientene (11). Ved å øke innholdet av fett i kosten og samtidig redusere inntaket av karbohydrater og proteiner induserte man metabolsk acidose og ketose, som man antok lå bak den antiepileptiske effekten. Senere dyreforsøk har vist at den anfallsreduserende effekten ikke nødvendigvis er knyttet til ketosen i seg selv (12). Studier med epilepsipasienter på ketogen diett viser at selv om ketosen forsvinner når dietten avsluttes, vedvarer den gode anfallssituasjonen for mange.

\section{Hovedbudskap}

- Flerumettede fettsyrer har antiepileptiske effekter i dyremodeller, men det er så langt ikke sikkert vist at de har anfallsreduserende effekt hos mennesker med epilepsi

- Den antiepileptiske effekten av ketogen diett kan delvis tilskrives flerumettede fettsyrer

- Flerumettede fettsyrer har også antiinflammatoriske effekter og kan virke gunstig på nevronenes energimetabolisme 
Dette kan skyldes at dietten har endret fettsyremetabolismen i hjernen, blant annet med et økt nivå av dokosaheksaensyre (7, 13). Det er vist at dietten gir økt mobilisering av flerumettede fettsyrer fra fettvev i lever og hjerne. Man antar at økningen i hjernen i hvert fall delvis kan forklare den anfallsreduserende effekten $(12,14)$. I tillegg tror man at tilstedeværelse av ketonlegemer og begrenset glukosetilgjengelighet kan ha betydning, uten at virkningsmekanismen er nærmere kjent.

I 1920- og 30-årene var det populært med ketogen diett, men den ble nærmest glemt etter at man fikk mer effektive antiepileptiske medikamenter. Det siste tiåret har dietten fått en renessanse. Den er nå i bruk ved de fleste epilepsisentre over hele verden, enten som et supplement til eller som alternativ til antiepileptika. I en åpen, randomisert studie publisert i The Lancet nylig fant man signifikant effekt av diettbehandlingen hos barn med epilepsi (15). Den klassiske ketogene dietten, med forutgående fasteperiode og streng kalori- og proteinrestriksjon, brukes mest hos barn med terapiresistent epilepsi. En modifisert Atkins-diett, der størsteparten av kaloriinnholdet kommer fra fett, men uten så streng karbohydrat-, proteinog væskerestriksjon, har vært forsøkt hos voksne med epilepsi (16).

I studier med barn behandlet med ketogen diett er det funnet signifikant korrelasjon mellom høyt nivå av arakidonsyre og bedret anfallskontroll $(6,8)$.

\section{Mekanismer bak den anfallsreduserende effekten}

Flere studier har vist at flerumettede fettsyrer virker antiepileptisk i cellekulturer $(6,8)$, som diett eller som infusjon i dyremodeller $(5,17)$ og som diett hos mennesker med epilepsi $(4,6)$. Det er ikke vist at enumettede fettsyrer og mettet fett har noen anfallsreduserende effekt ved epilepsi. Mekanismene bak den anfallsreduserende effekten til de flerumettede fettsyrene er ikke fullt ut klarlagt, men det antas å være flere ulike. Inkorporert i cellemembraner kan flerumettede fettsyrer påvirke membranfluiditeten, som frie omega-3-fettsyrer kan de påvirke intracellulære funksjoner.

\section{Effekt på cellesignaler}

Fettsyrer kan modulere den elektriske ledningen i cellene ved å påvirke ionekanalfunksjoner og reseptorsystemer (12). Enkelte antiepileptika (karbamazepin, fenytoin, valproat), noen antiarytmika (lidokain) og flerumettede fettsyrer interagerer i et felles reseptorsete på natriumkanalen. Det er vist at arakidonsyre og dokosaheksaensyre kan blokkere spenningsstyrte natriumkanaler i hippocampusnevroner $(5,18)$. Ved intracellulær registrering av elektrisk stimulerte nevroner i striatum pyramidale fant man at dokosaheksaensyre signifikant hemmet repetitive aksjonspotensialer. Omega-3- fettsyren dokosaheksaensyre virker antiepileptisk gjennom frekvensavhengig blokkering av natriumkanaler, der membranpotensialet hyperpolariseres og refraktærperioden forlenges $(14,18)$.

At antiepileptika som fenytoin og karbamazepin virker på natriumkanalen, har gjort at man tenker seg at flerumettede fettsyrer er den endogene liganden som disse etterlikner. Dokosaheksaensyre og eikosapentaensyre kan i tillegg redusere den nevronale eksitabiliteten gjennom en påvirkning av kaliumkanaler.

Det er også vist at flerumettede fettsyrer stimulerer aktiviteten til natrium-kaliumpumpen (12). Økt pumpeaktivitet reduserer den nevronale eksitabiliteten ved å hyperpolarisere cellen og redusere hvilemembranpotensialet. En økning av flerumettede fettsyrer i hjernen kan altså redusere den nevronale hypereksitabiliteten som man ser hos mennesker med epilepsi.

\section{Effekt på inflammasjon}

I de senere år har mye av forskningen på omega-3-fettsyrer dreid seg om deres mulige antiinflammatoriske effekt. Hos epilepsipasienter og i dyremodeller av epilepsi er det i det epileptiske cellenettverket funnet tegn til kronisk inflammasjon, gjennom høye nivåer av eikosanoider $(6,19)$. Eikosanoider er lokale hormonliknende signalmolekyler (prostaglandiner, tromboksaner og leukotriener) som har proinflammatorisk effekt. Økt omega-3-inntak reduserer kronisk inflammasjon, og dette kan synes å ha en anfallsreduserende effekt i seg selv (6).

En pilotstudie viste at pasienter med kronisk refraktær epilepsi som fikk tilført omega-3 daglig i tre måneder, hadde lavere membranmetabolisme enn placebogruppen (19). Spektroskopiundersøkelser viste økt energiproduksjon og markant forhøyet nivå av fosfolipider i hjernen hos pasientene. Men det er hittil ikke vist at disse endringene påvirker anfallssituasjonen. Likevel kan det synes som mennesker med intraktabel epilepsi har uheldige biokjemiske forandringer i hjernen, og at tilførsel av omega-3 kan ha en gunstig membranstabiliserende og antiinflammatorisk effekt, kanskje også en nevroprotektiv effekt (12).

\section{Kliniske studier}

Hvis man ser bort fra studier med epilepsipasienter som får en ketogen diett, er det kun utført noen få kliniske studier der man har sett på effekten av flerumettede fettsyrer ved epilepsi.

Schlanger og medarbeidere gjennomførte i 2002 en åpen studie av pasienter med refraktær epilepsi (4). Daglig tilskudd av flerumettede fettsyrer i form av 2,3 g dokosaheksaensyre, $900 \mathrm{mg}$ eikosapentaensyre, 50 $\mathrm{mg}$ arakidonsyre og vitamin $\mathrm{E}$ ble gitt som pålegg på maten i seks måneder. Før intervensjonen hadde pasientene 1-14 anfall/ uke. Anfallsfrekvensen etter avsluttet be-
Tabell 1 Fettsyrer i enkelte matsorter

\begin{tabular}{ll} 
Kilde & Flerumettet fettsyre \\
$\begin{array}{l}\text { Vegetabilske oljer } \\
\text { Grønne grønnsaker }\end{array}$ & Alfalinolensyre \\
\hline Fet fisk & Eikosapentaensyre \\
\hline Fet fisk & Dokosaheksaensyre \\
Vegetabilske oljer & Linolsyre \\
\hline
\end{tabular}

handling var 0-1/måned. Anfallsreduksjonen kom hovedsakelig i slutten av studieperioden, og forfatterne postulerer at den anfallsreduserende effekten av flerumettede fettsyrer først kommer etter lengre tids behandling. Dessverre hadde studien alvorlige begrensninger - det var ingen kontrollgruppe, studien var ikke blindet, og kun fem av i alt 21 pasienter fullførte. Det var ingen overgang til vanlig kosthold og ingen forsøk på å variere doseringen av kosttilskuddet.

Den første randomiserte, placebokontrollerte kliniske studien av flerumettede fettsyrer ved epilepsi ble publisert i 2005 (6). Det var en 12 ukers dobbeltblindet, placebokontrollert parallellgruppestudie med kosttilskudd av $1,0 \mathrm{~g}$ eikosapentaensyre og $0,7 \mathrm{~g}$ dokosaheksaensyre daglig til 57 pasienter med minst fire anfall/måned i en basisperiode på tre måneder. Sammenliknet med placebogruppen oppnådde signifikant flere i behandlingsgruppen mer enn $50 \%$ anfallsreduksjon de første seks ukene. Deretter sank effekten, slik at det etter 12 uker ikke var noen forskjell mellom gruppene. Blodprover viste at behandlingsgruppen oppnådde en signifikant økning i eikosapentaensyre og dokosaheksaensyre i serum og i erytrocytter og et tilsvarende fall $i$ arakidonsyre.

I en nylig publisert studie fikk 21 epilepsipasienter etter randomisering enten omega-3-tilskudd eller placebo $i$ en 12 ukers blindet behandlingsperiode (20). Man fant at anfallsfrekvensen økte i behandlingsgruppen og sank i placebogruppen. Studien ble etterfulgt av en åpen oppfølgingsperiode med omega-3-tilskudd. I denne perioden hadde 15 av 19 pasienter lavere anfallsfrekvens enn $\mathrm{i}$ basisperioden.

\section{Konklusjon}

De få kliniske studiene med flerumettede fettsyrer som hittil er gjennomført, har ikke vist den samme anfallsreduserende effekten som man ville forvente ut fra dyrestudiene.

Videre forskning med forskjellige doser og fettsyresammensetninger, og kanskje med lengre behandlingsperioder, er nødvendig før man kan si noe mer sikkert om den kliniske nytteverdien av flerumettede fettsyrer $i$ behandlingen av personer med epilepsi.

Oppgitte interessekonflikter: Ingen 


\section{Litteratur}

1. Kwan P. Brodie MJ. Epilepsy after the first drug fails: substitution or add-on? Seizure 2000; 9: 464-8.

2. Mazza M, Pomponi M, Janiri L et al. Omega-3 fatty acids in neurological and psychiatric diseases: an overview. Prog Neuropsychopharmacol Biol Psychiatry 2007; 31: 972-3.

3. Shapiro H. Could n-3 polyunsaturated fatty acids reduce pathological pain by direct actions on the nervous system? Prostaglandins Leukot Essent Fatty Acids 2003; $68: 219-24$

4. Schlanger S, Shinitzky M, Yam D. Diet enriched with omega-3 fatty acids alleviates convulsion symptoms in epilepsy patients. Epilepsia 2002; 43 $103-4$.

5. Voskuyl RA, Vreugdenhil M, Kang JX et al. Anticonvulsant effect of polyunsaturated fatty acids in rats, using the cortical stimulation model. Eur J Pharmacol 1998; 341: 145-52.

6. Yuen AW, Sander JW. Fluegel D et al. Omega-3 fatty acid supplementation in patients with chronic epilepsy: a randomized trial. Epilepsy Behav 2005: 7: $253-8$.

7. Dahlin M, Hjelte L, Nilsson S et al. Plasma phospholipid fatty acids are influenced by a ketogenic diet enriched with n-3 fatty acids in children with epilepsy. Epilepsy Res 2007; 73: 199-207.

8. Fraser DD, Whittng S, Andrew RD et al. Elevated polyunsaturated fatty acids in blood serum obtained from children on the ketogenic diet. Neurology 2003; 60: 1026-9.

9. Stafstrom CE. Dietary approaches to epilepsy treatment: old and new options on the menu. Epilepsy Curr 2004; 4: 215-22.

10. Retterstøl K. Fettsyrebalanse. Tidsskr Nor Lægeforen 2000; 120: 3166.

11. Wilder RM. The effect of ketonemia on the course of epilepsy. Mayo Clin Bull 1921; 2: 307-8.

12. Bough KJ, Rho JM. Anticonvulsant mechanisms of the ketogenic diet. Epilepsia 2007; 48: 43-58.

13. Taha AY, Ryan MA, Cunnane SC. Despite transient ketosis, the classic high-fat ketogenic diet induces marked changes in fatty acid metabolism in rats. Metabolism 2005; 54: 1127-3.

14. Cunnane SC, Musa K, Ryan MA et al. Potential role of polyunsaturates in seizure protection achieved with the ketogenic diet. Prostaglandins Leukot Essent Fatty Acids 2002; 67: $131-5$

15. Neal E, Chaffe H, Schwartz R et al. The ketogenic diet for the treatment of childhood epilepsy: a randomised controlled trial. Lancet Neurol 2008; 7 : $500-6$.

16. Kossoff EH, Rowley H, Sinha S et al. A prospective study of the modified Atkins diet for intractable epilepsy in adults. Epilepsia 2008: 49: 316-9.

17. Rabinovitz S, Mostofsky DI, Yehuda S. Anticonvulsant efficacy, behavioral performance and cortisol levels; a comparison of carbamazepine (CBZ) and a fatty acid compound (SR-3). Psychoneuroendocrinology 2004; 29: 113-24.

18. Young C, Gean PW, Chiou LC et al. Docosahexaenoic acid inhibits synaptic transmission and epileptiform activity in the rat hippocampus. Synapse 2000; 37: $90-4$.

19. Puri BK, Koepp MJ, Holmes J et al. A 31-phosphorus neurospectroscopy study of omega-3 longchain polyunsaturated fatty acid intervention with eicosapentaenoic acid and docosahexaenoic acid in patients with chronic refractory epilepsy. Prostaglandins Leukot Essent Fatty Acids 2007; 77 $105-7$.

20. Bromfield E, Dworetzky B, Hurwitz S et al. A randomized trial of polyunsaturated fatty acids for refractory epilepsy. Epilepsy Behav 2008; 12 $187-90$ 